\section{Investigation of the Effects of Applying Social Sustainability Components on Residential Satisfaction}

\section{Mohammadhossein Azizibabani, Mohammadreza Bemanian*, Mansour Yeganeh}

Faculty of Art, Tarbiat Modares University, Tehran, Iran

*Corresponding author: Bemanian@modares.ac.ir

\section{Гrossef}

http://dx.doi.org/10.5755/j01.sace.29.2.29217
Today, decades after the emergence of the concept of sustainable development, the long-term positive effects of achieving sustainable development goals in all environmental, economic, and social dimensions on the quality of human life are undeniable. The purpose of this research is to explain the mechanism of effects of applying the social sustainability components on the level of residential satisfaction in the scale of residential complexes. The research uses a mixed (quantitative and qualitative) methodology in terms of the nature of the data and the research method is descriptive-analytical (causal and comparative). The conceptual model of the research, which includes the relationships between the variables of perceived quality of social sustainability components, residential desires associated with these components, perceived quality of housing architecture, and residential satisfaction, has been proposed based on the study of theoretical foundations through logical reasoning method. This model has been tested through obtained data from a questionnaire in a field study conducted in the Baghe Behesht residential complex in the Saadatabad neighborhood of Tehran. According to the results, the application of the components of social sustainability has a significant effect on residential satisfaction by improving the quality of housing architecture, and in conditions of qualitative deficiency in social sustainability components, residential desires associated with these components will reduce the perceived quality and the level of residential satisfaction.

Keywords: social sustainability, residential satisfaction, residential desires, perceived quality, residential complex.

Nowadays, moving towards achieving sustainable development goals in various fields, including architecture and urban planning, is known as a necessity than a choice. The application of the components of sustainable design in architecture is the main solution to achieve the goals of sustainable development in this field. In this regard, most of the conducted researches have focused on the environmental and economic dimensions of sustainability. The goals related to these two dimensions of this concept will be mainly achieved by conserving resources and energy and moving towards the use of renewable energies in the long term. In addition to finding a comprehensive solution for environmental and economic considerations, the main challenge of sustainable architecture is achieving an appropriate level of quality of life and preserving cultural and social values along with providing environmental comfort (Kim, 1998). The second part of this challenge
JSACE 2/29

Investigation of the Eeffects of Applying Social Sustainability Components on Residential Satisfaction

Received 2021/06/07

Accepted after revision 2021/07/13

\section{Introduction}

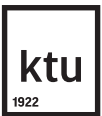

Journal of Sustainable Architecture and Civil Engineering Vol. 2 / No. 29 / 2021 pp. 49-61 DOI 10.5755/j01.sace.29.2.29217 
which is related to residential buildings is more important, and also is presented as a subset of social sustainability issues.

Social sustainability is based on the general view of the status of social justice for the present and future generations and adherence to its principles can affect activities related to the construction of residential environments. Although the issue of energy and resource consumption in residential buildings, especially in developing countries, is important and this is related to environmental and economic goals of sustainability, but providing comfort and tranquility in residential environments is a vital point. It should be noted that achieving the desired goals should be in the short term or at the very beginning of the work cycle of residential buildings. In fact, this refers to the well-known definition of sustainable development, which was presented in the Brundtland Report as follows: development that meets the needs of the present without compromising the ability of future generations to meet their own needs (WCED, 1987). Therefore, improving the quality of life through environmental design is an issue that has been addressed as the concept of residential satisfaction.

The concept of satisfaction refers to a wide range of desires to meet the basic or transcendent needs of human beings (Rafieian, Aminsalehi, \& Taghvaei, 2011) which are necessary to ensure human comfort and tranquility in residential environments. Numerous factors including cultural, economic, household livelihoods, climatic conditions, and construction technologies affect the formation of housing and urban fabrics and housing has mutually a significant effect on the lifestyle and cultural pattern of residence. Therefore, housing is considered beyond a basic need for human beings. In this regard, residential satisfaction is a concept based on the perception of space and depends on the quality of responding to a set of residential needs that are rooted in culture, lifestyle, geography and climate. In definition, residential satisfaction is the result of peoples' understanding of the differences between their preferences and aspirations and standards and the actual housing conditions (Campbell, Converse, \& Rodgers, 1976). In other words, residential satisfaction is the result of the comparison between residential conditions and residential desires that several factors, including cultural, economic conditions and social status of residents play a role in this analogy.

The environmental and economic effects of applying sustainability components in architecture are more tangible on large scales that may not affect the quality of human life directly. Therefore, the present research has investigated the effects of the architectural application of social sustainability components on the level of residential satisfaction at the residential complexes scale. This research was carried out aimed to explain the mechanism of the relationship between the quality of social sustainability components in architecture and the level of residential satisfaction. In this regard, the following questions are raised:

Which components of social sustainability in architecture play a key role in improving the level of residential satisfaction?

How is the mechanism of the effect of social sustainability components on the quality of housing architecture and residential satisfaction?

This research uses a mixed (quantitative and qualitative) methodology in terms of the nature of the data and the research method is descriptive-analytical (causal and comparative). Theoretical foundations and literature have been reviewed to identify the components and indicators of social sustainability in architecture, and residential satisfaction in the scale of the architectural quality of residential complexes. To extract the indicators related to the mentioned variables, the content analysis method has been used. In this regard, the content unit is sentences and words that were related to the variables. Categories and subcategories have been extracted from the existing literature and then have been classified. The conceptual model of the research and relationships between the variables have been determined using the logical reasoning method. The conceptual model should be tested in an experimental study, so the Baghe Behesht residential complex in the 
Saadatabad neighborhood of Tehran city has been considered as a case study. The data related to the variables have been obtained through a questionnaire and the method of path analysis was used to verify the conceptual model. To answer the first research question, regression analysis on the collected data has been used to determine the key components of social sustainability in improving the level of residential satisfaction. In this analysis, the level of residential satisfaction has been considered as a dependent variable on the application of the components of social sustainability. Concerning the second question, the conceptual model of the research has been evaluated through the Amos-Version 24 software.

\section{The concept of residential satisfaction}

Studies on residential satisfaction can be divided into three categories based on the general view, objectives, and scope of research. According to the general view, a group of researchers investigated residential satisfaction as a criterion for determining the quality of the living environment (Marans \& Rodgers, 1975; Galster \& Hesser, 1981; Cutter, 1982). The other researchers consider this concept as a predictor of the residents' behavior regarding residential mobility, improving housing status, or adaptation to the current situation (Separe, 1974; Premius, 1986). According to the objectives, researches on residential satisfaction are divided into three categories. Some researchers have sought to determine the relationships between factors affecting residential satisfaction (Garcia, 1994; Amerigo \& Aragones, 1997; Varady, Preiser, \& Wolfgang, 1998; Parkes, Kearns, \& Atkinson, 2002; Choudhury, 2005; Fallahi, Hariza, Husniyah, \& Abdul Rahim, 2015). Some other researchers have focused on predicting residential satisfaction in residential environments (Theodori, 2001; Ogu, 2002). Moreover, the third group of researchers has investigated settlements based on factors affecting residential satisfaction (Lu, 1999; Russell \& James, 2008; Azimi \& Esmaeilzadeh, 2017; Azizibabani \& Bemanian, 2019). According to the scope, researches on residential satisfaction are divided into three categories. A group of researchers has investigated residential satisfaction at the scale of urban apartments to residential complexes (Zabihi, Habib, \& Rahbarimanesh, 2011; Abbaszadeh, Gohari, \& Askari Rabori, 2017). Another group has examined this concept at the neighborhood or urban scale (Dekker, de Vos, Musterd, \& van Kempen, 2011; Azemati, Pourbagher, \& Rostami, 2017). Moreover, another group has examined this concept on the scale of urban geography (Theodori, 2001).

The concept of residential satisfaction contains a wide range of studies, but most of them were empirical and haven't led to a theoretical model or theory. Therefore, Basic theoretical studies on the concept of residential satisfaction are listed in Table 1.

\section{The concept of social sustainability}

The emergence of the concept of social sustainability coincided with the presentation of the Brundtland report on various dimensions of sustainable development in 1987. In the beginning, the environmental dimension of sustainable development was more important compared to other dimensions, but over time the importance of all environmental, economic, and social dimensions was equal in development-related activities (Colantonio \& Lane, 2007). The social dimension of sustainable development provides the context for strengthening social solidarity, increasing the level of social interactions, and creating equality for access to public facilities such as health, education, transportation, housing, etc (McKenzie, 2004). According to Qanbari and Farhadi (2017), the foundations of sustainable social development are equality (creating equal opportunities for all members of society), diversity (possibility of racial and cultural diversity), solidarity, quality of life (meeting basic needs and hierarchical needs), and democratic government. Thin et al. (2002), introduce social justice, social solidarity, participation, and security as four criteria of sustainable social development. Murphy (2012) concluded that the four main pillars of social sustainability are justice, participation, awareness for sustainability and social solidarity. Weingaertner and Moberg

\section{Theoretical Foundations}


Table 1

Basic theoretical research on the concept of residential satisfactio

\begin{tabular}{l|l|l}
\multicolumn{1}{c|}{ Title } & Researcher & \multicolumn{1}{c}{ Description } \\
\hline $\begin{array}{l}\text { Sociological } \\
\text { Theory of Home }\end{array}$ & $\begin{array}{l}\text { Reimer, } \\
\text { Adjustment }\end{array}$ & $\begin{array}{l}\text { According to this theory, the variables that determine human residential } \\
\text { needs change under the influence of two factors of time and type of house- } \\
\text { hold. }\end{array}$ \\
\hline $\begin{array}{l}\text { Residential Mo- } \\
\text { bility }\end{array}$ & $\begin{array}{l}\text { According to this theory, residential mobility is defined as a natural part of } \\
\text { every family life cycle. Therefore, people change their place of residence to } \\
\text { meet their residential needs that are affected by time. Some of the most im- } \\
\text { portant factors affecting the change of residential needs and desires that have } \\
\text { been discussed in the context of this theory are the number of family mem- } \\
\text { bers, aging, and changing social status of the family. After the emergence of } \\
\text { this theory, the concept of residential mobility was more investigated in the } \\
\text { researches. }\end{array}$ \\
\hline $\begin{array}{l}\text { Migration as an } \\
\text { Adjustment to } \\
\text { Environmental } \\
\text { Stress }\end{array}$ & $\begin{array}{l}\text { (1955) } \\
\text { (Wolpert, }\end{array}$ & $\begin{array}{l}\text { Wolpert believed that the hypotheses about economic, climatic, aesthetic, etc. } \\
\text { factors regarding residential mobility are all minor factors and none of them } \\
\text { can be considered as a determining criterion in the residential mobility behav- } \\
\text { ior of residents. He believed that environmental stress is a determining factor } \\
\text { in residents' behavior regarding residential mobility in an urban environment, } \\
\text { and some of the sub-factors of stress include heavy traffic, noise, light, air and } \\
\text { water pollution, and lack of outdoor space. He developed an environmental } \\
\text { model which showed the impact of these variables on the migration decision } \\
\text { of residents. }\end{array}$ \\
\hline
\end{tabular}

Morris and Winter provide a conceptual and theoretical framework for studying the behavior of households in adapting to a residential environment. According to their theory, each family evaluates its housing according to cultural and family norms and seeks to meet the normative housing deficits. Residential mobility, relocation based on household needs, or adjustment of the family desires and needs based on current housing status are some of the measures that can be taken in this regard which may be done when restrictions prevail over behavioral patterns.

Marans \& Rodgers have presented a conceptual framework based on Maslow's (1958) theory of the level of human needs to determine the quality of urban life in three spatial scales, which includes objective and subjective data. These three spatial scales include community (country-city), neighborhood, and private home. According to this theory, people's assessment of their satisfaction in the three mentioned scales depends on their personal characteristics and residential satisfaction in every scale affects the others.

Fig. 1. A broad model framework for investigating subjective assessment of determinants of satisfaction with the residential environment

\begin{tabular}{l|l}
$\begin{array}{l}\text { A Theory of The } \\
\text { Purposes of }\end{array}$ & $\begin{array}{l}\text { Marans \& } \\
\text { Rodgers, }\end{array}$ \\
Human Life & $1975)$
\end{tabular}

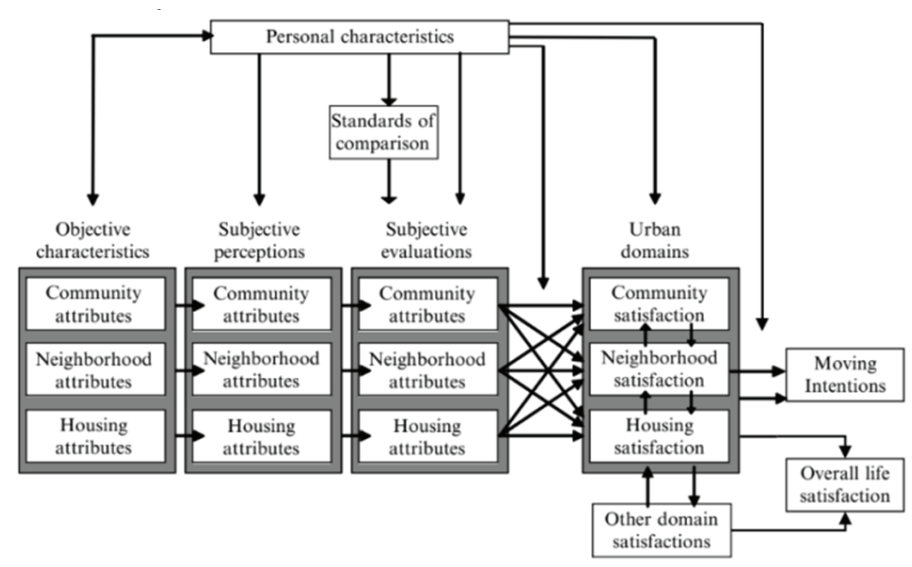

Source: (Marans \& Rodgers, 1975) 


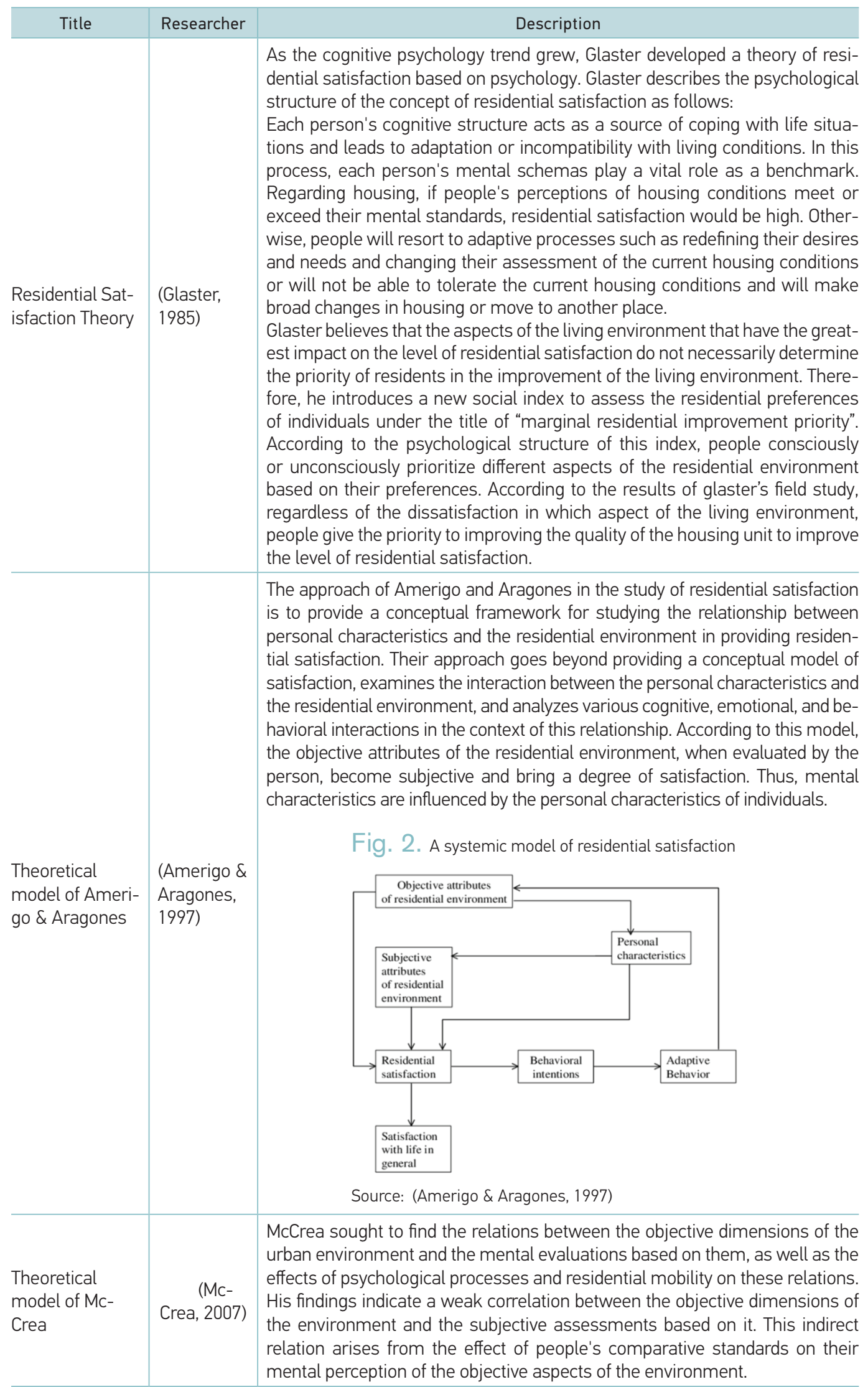


(2011) recognized accessibility (job, open space, neighborhood services), social capital, health, social cohesion, local participation, and a sense of place as indicators of social sustainability.

The theoretical foundations of social sustainability show that any actions that might change basic social relations are not acceptable in the process of development. The purposes of any kind of development should more focus on improving the quality of humans' life and meeting their needs. Therefore, the general strategy regarding the issue of social sustainability is social development based on responding to welfare, cultural and psychological needs, the need for adaptability, and the need for growth and prosperity (Nazarpour, 2000). The components of social sustainability can be summarized into four groups: social justice, security, participation, and standard (quality) of living. The indicators of these components, which are related to the design of the environment, are shown in Table 2. A part of the questionnaire which was distributed among participants (Residents of the Baghe Behesht complex) was based on measuring the perceived quality of these indicators in the living space, and the other part measures their willingness to apply these indicators.

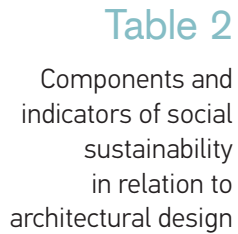

Table 2

\begin{tabular}{l|l|c}
\hline \multicolumn{1}{|c}{ Components and indicators } & No \\
\hline \multirow{4}{*}{ Social justice } & Access to the facilities & 1 \\
\cline { 2 - 3 } & The similarity of units in having good light and view & 2 \\
\cline { 2 - 3 } & Proper access to municipal services & 3 \\
\hline \multirow{5}{*}{ security } & Physical security in the interior spaces & 4 \\
\cline { 2 - 3 } participation & Feeling of Psychological security in the interior spaces & 5 \\
\hline & Physical security in the open spaces of the residential complex & 6 \\
\hline & Feeling of Psychological security in the open spaces of the residential complex & 7 \\
\hline \multirow{3}{*}{ Standard of living } & A sense of belonging to the complex & 8 \\
\cline { 2 - 3 } & Opportunity to establish social interactions with neighbors & 10 \\
\hline & Quality of environmental comfort inside residential units & 11 \\
\cline { 2 - 3 } & Quality of environmental comfort in open and semi-open spaces of the complex & 12 \\
\cline { 2 - 3 } & Quality of housing response to residential needs & 9 \\
\hline
\end{tabular}

Derived from: (Qanbari \& Farhadi, 2017; Murphy, 2012; Weingaertner \& Moberg, 2011; Thin, Lockhart, \& Yaron, 2002)

\section{The effects of the Components of Social Sustainability on Residential Satisfaction}

Regarding the relationship between social sustainability and residential satisfaction, Karuppannan \& Sivam (2011) examined the impact of urban form on social sustainability and residents' satisfaction at the neighborhood level. The results of this study demonstrated that the provision of high quality and well-located open space at the precinct level, mixed land use and good accessibility to the public realm and social infrastructure play an important role in increasing social sustainability and residents' satisfaction. Howley et al. (2009) believe that it is not only high density per se that is the source of dissatisfaction for residents but rather other related factors such as environmental quality, noise, lack of community involvement, traffic and lack of services and facilities. Ríos \& Moreno-Jiménez (2012) focused on the concepts of place identity, social identity, residential satisfaction and community participation among immigrant and native populations. They found that greater place identity was seen to be linked with greater community participation and residential satisfaction. Ibrahim (2020) assessed the level of satisfaction with public housing offered by the UAE government to its citizens. The survey results show that the majority of residents are mostly satisfied, although the overall level of satisfaction with the functionality of the building and public facilities provided was generally higher than that related to the social environment in the residential district. 
According to the results obtained from the study of basic theories on the concept of residential satisfaction, the scale of the investigation of this concept is important in determining the variables and indicators involved. In the case of measuring residential satisfaction on the scale of residential complexes, three main variables play role in determining residential satisfaction as follows:

The quality of housing architecture, which includes formal, functional, and semantic dimensions. Quality of social sustainability components and finally, residential desires associated with social sustainability. Another point about the qualities of variables is the necessity to measure the perceived qualities, which is possible to measure their impacts on residential satisfaction. The variables of residential desires associated with social sustainability and perceived quality of social sustainability were measured in the four titles of social justice, participation, security, and standard of living by the 12 indicators mentioned in Table 1. The measurement of the perceived quality of housing architecture has also been done in three material, psychological and semantic dimensions as described in Table 3.

\begin{tabular}{l|l|c}
\hline \multicolumn{2}{|c}{ Qualitative aspects of housing architecture } & No \\
\hline \multirow{3}{*}{ Semantic quality } & Using symbols and signs formed based on culture and beliefs & 1 \\
\cline { 2 - 3 } & Transfer of concepts through using semantic components such as light, water, etc. & 2 \\
\cline { 2 - 3 } & Application of various geometries in the plan to transmit meanings of shapes & 3 \\
\cline { 2 - 3 } & Using various colors and textures to transmit their related meanings & 4 \\
\hline \multirow{3}{*}{ Functional quality } & Providing physical security and environmental comfort & 5 \\
\cline { 2 - 3 } & Compatibility of dimensions of spaces with considered functions & 6 \\
\cline { 2 - 3 } & Quality of functional relationships between spaces & 7 \\
\hline & Preserving static and visual balance in architectural forms & 9 \\
\cline { 2 - 3 } & The aesthetic quality of the design & 10 \\
\cline { 2 - 3 } & Compatibility of architectural forms with the surrounding urban fabric & 9 \\
\hline
\end{tabular}

Derived from: (Bemanian \& Zandi, 2018; Altman, 1975; Naghizadeh, 2012; Raeisi, 2019; Pirnia, 1997)

Determinant indicators of residential satisfaction are defined based on meeting the residential needs of the target community according to Table 4 . The validity of the questionnaire was confirmed by interviewing a group of experts, and the indicators for measuring the variables were developed on this basis.

\begin{tabular}{|c|c|c|}
\hline & Residential satisfaction indicators based on meeting residential needs & No \\
\hline \multirow{4}{*}{$\begin{array}{l}\text { Residential } \\
\text { needs of the } \\
\text { material di- } \\
\text { mension }\end{array}$} & Responding to physical functions & 1 \\
\hline & Providing physical security & 2 \\
\hline & Providing necessary daylight for spaces & 3 \\
\hline & Providing climatic comfort & 4 \\
\hline \multirow{4}{*}{$\begin{array}{l}\text { Residential } \\
\text { needs of the } \\
\text { psychological } \\
\text { dimension }\end{array}$} & Preservation of individual and family boundaries & 5 \\
\hline & Providing a context for understanding sensory beauty & 6 \\
\hline & Inducing a sense of peace and Psychological security & 7 \\
\hline & Providing a context to promote social interactions & 8 \\
\hline \multirow{3}{*}{$\begin{array}{l}\text { Residential } \\
\text { needs spiritu- } \\
\text { al dimension }\end{array}$} & Providing a context for individual and family privacy & 9 \\
\hline & Providing a context for understanding the concepts of natural phenomena & 10 \\
\hline & Providing a context to understand the spiritual beauty and flourishing of cultural values & 11 \\
\hline
\end{tabular}

\section{Table 4}

Indicators of residential satisfaction based on meeting residential needs

Derived from: (Raeisi, 2019; Bemanian \& Zandi, 2018; Altman, 1975; Azizibabani \& Bemanian, 2019) 
The theoretical framework of the research is explained based on the relationship of variables so that the residential desires of residents regarding the application of the components of social sustainability in architecture form the basis of initial expectations and are considered as an independent variable in this study. Although personal and cultural factors affect these residential desires but examining how they are affected is not within the scope of this study. Perceived quality of applying indicators of social sustainability has been considered as a dependent of mentioned residential desires. In this regard, it is hypothesized that the perceived quality of a component will decrease due to the increase

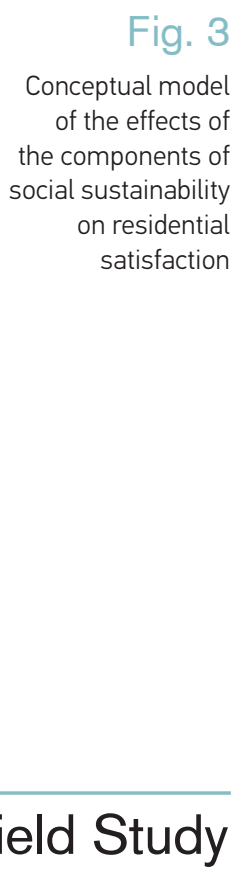

Fig. 4

(1) Hierarchy in the open spaces of the complex. (2) Overview of the complex from the south side. (3) Semipublic spaces for social interactions. (4) Forest parks on the south side of the complex

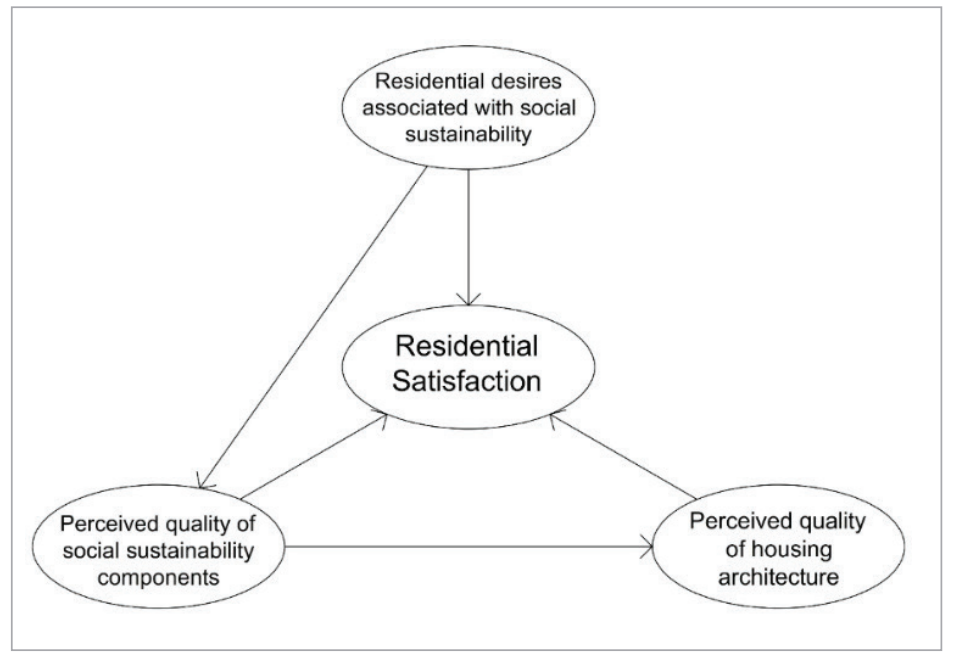

in its related residential desire, and the reason for such a hypothesis is the increase in the level of initial expectations about that component. In addition, the variable of perceived quality of housing architecture is affected by the perceived quality of social sustainability components and all three variables will affect residential satisfaction. The conceptual model of these relations is depicted in Fig. 3.

Source: Authors

To verify the conceptual model and answer the research questions, the mentioned relations between the variables should be tested in a real context. In this regard, Baghe Behesht residential complex located in Saadatabad neighborhood of Tehran has been selected due to having a desirable level of indicators related to the variables of the conceptual model. The level of occupancy in the complex is such that the dominance of open spaces over masses is evident, and the landscape design of this complex has

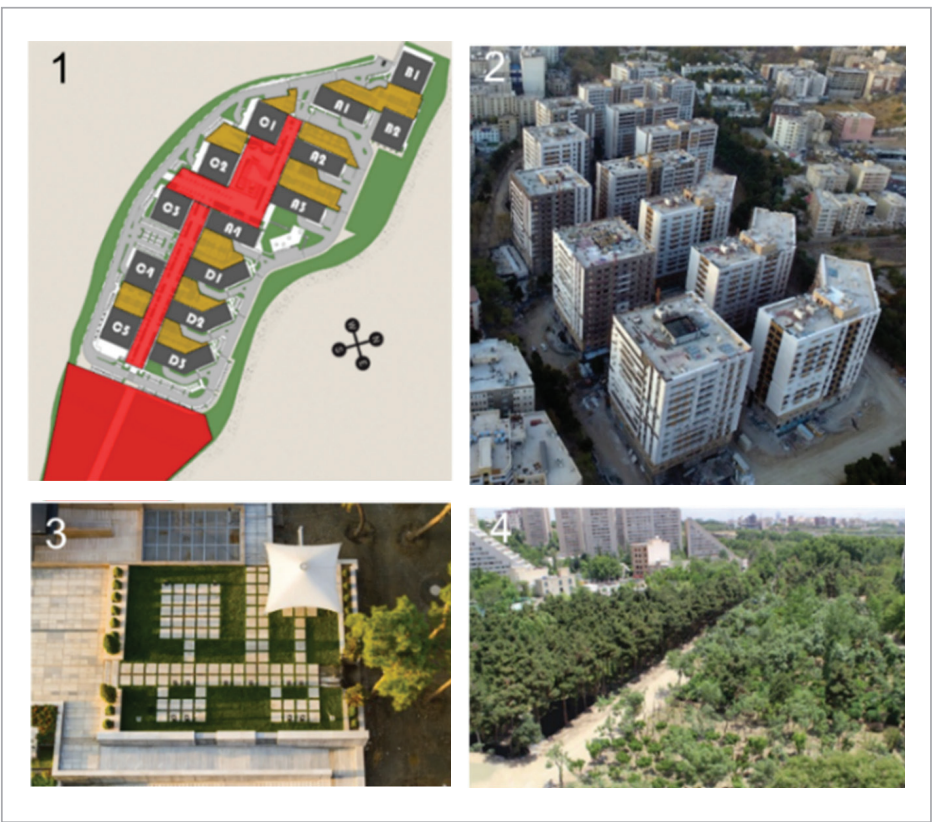

Source: Authors led to improving the quality of social interaction spaces between residents.

The forest park on the south side of the complex, which is exclusively available to residents, is considered as a context for social interactions between them. The hierarchy of public, semi-public, and semi-private spaces in the level of the complex is customary observed, and the proper separation of pedestrian paths from vehicle paths has made it possible to form the context of interactions of different social groups from residents of a block to residents of a 
neighborhood unit and residents of the whole complex. The physical control of the interior spaces of the complex and the inclusion of active and passive surveillance in the open spaces has led to an increase in the quality of indicators of physical security. Also, the design of the site and locating of the masses have been done based on the climatic characteristics of Tehran, which leads to the provision of comfortable conditions to an acceptable level at the participatory spaces.

A questionnaire with the participation of 251 residents was used to measure the variables related to the conceptual model and explain the relationship between them. Data were collected and analyzed between January to April 2021. The questionnaire which was designed based on a 5-point Likert scale, consists of 45 questions in four sections that directly measure the indicators presented in Tables 2,3 , and 4. Regarding the 12 indicators of Table 2, in addition to the perceived quality, residential desires have also been measured. In addition to these 45 questions, demographic data including age, gender, marital status, ownership status, and length of residence in the complex were also collected. However, the study of the effects of demographic variables on conceptual model variables has not been in the scope of this research and no strong statistical relationship was found in this regard. The average percentage of each of the indicators related to the research variables is shown in the Fig. 5 .

Regarding the first research question, the results of regression analysis of the relationship between different components of the perceived quality of social sustainability with the residential satisfaction show that the role of the component of the standard of living in predicting changes of residential satisfaction variable was more than other components. In this model, R Square $=0.468$.

Regarding the second question of the research, according to the results of the conceptual model test based on quantitative data, residential desires related to social sustainability components have had a reverse effect on the perceived quality of these components and residential satisfaction. There is also a direct relationship between the perceived quality of social sustainability components and
Fig. 5

Average percentage of indicators related to research variables
Results 
the perceived quality of housing architecture and residential satisfaction. Amos-Version 24 was used to determine the degree of these relations, which the results are shown in Fig. 6.

Table 5

Regression model of the relationship between perceived quality of the components of social sustainability and residential satisfaction

\begin{tabular}{|c|c|c|c|c|c|c|}
\hline \multicolumn{7}{|c|}{ Coefficients $^{a}$} \\
\hline & \multirow[t]{2}{*}{ Model } & \multicolumn{2}{|c|}{$\begin{array}{l}\text { Unstandardized } \\
\text { Coefficients }\end{array}$} & \multirow{2}{*}{$\begin{array}{c}\text { Standardized } \\
\text { Coefficients } \\
\text { Beta }\end{array}$} & \multirow[t]{2}{*}{$\mathrm{t}$} & \multirow[t]{2}{*}{ Sig. } \\
\hline & & B & Std. Error & & & \\
\hline \multirow{5}{*}{1} & (Constant) & .136 & .031 & & 4.336 & .000 \\
\hline & Perceived quality of the justice component & .147 & .033 & .277 & 4.374 & .000 \\
\hline & Perceived quality of the security component & .201 & .042 & .306 & 4.766 & .000 \\
\hline & Perceived quality of the participation component & .081 & .040 & .133 & 2.029 & .044 \\
\hline & Perceived quality of the standard of living component & .360 & .057 & .405 & 6.375 & .000 \\
\hline
\end{tabular}

a. Dependent Variable: Residential satisfaction

Source: Authors

Fig. 6

The results of conceptual model path analysis

\section{Discussion and Conclusion}

According to the results of the analysis of the data obtained from the field study, the variable of residential satisfaction in the scale of the architectural quality of residential complexes is a func-

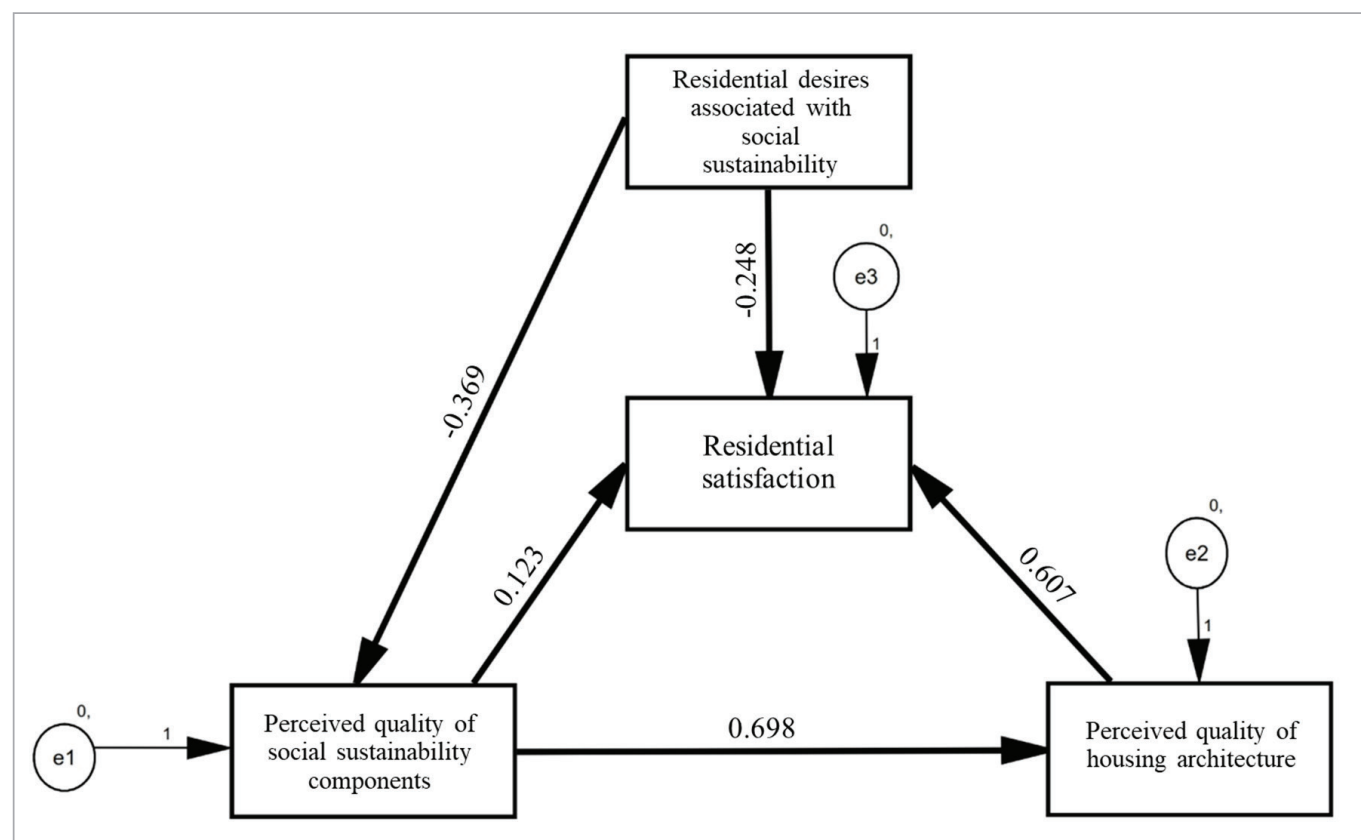

Source: Authors

tion of the variables of perceived quality of housing architecture, perceived quality of application of the components of social sustainability and residential desires associated with these components. Beta coefficients in the model show that the variables of residential desires associated with the components of sustainability and perceived quality of housing architecture had a direct impact on residential satisfaction, but the perceived quality of sustainability components didn't have a significant impact on residential satisfaction and this variable has a significant effect on the residential satisfaction through the variable of housing architecture quality. As residential desires associated with the components of social sustainability increase, the perceived quality of these components and residential satisfaction will decrease equally due to the level of expectations increases. It can 
be interpreted that in proportion to the increase in the human desire for a particular aspect of the quality of a product, its shortcomings attract more human attention and lead to dissatisfaction with the performance of the product. Therefore, the quality deficiency in these components should be noted in interpreting the inverse relationship between the variables involved in the research model. In other words, in situations where the quality of the sustainability components is somewhat high, there will be no relationship between perceived quality, desires, and residential satisfaction, or this relationship will not necessarily be reversed.

In addition, it is concluded that the perceived quality of the component of living standards, which is generally related to the housing response to human residential needs, has the greatest impact on improving the quality of housing and the level of residential satisfaction. Subsequently, residential satisfaction resulting from the application of the components of social sustainability in architecture has been due to the improvement of living standards by improving the quality of housing architecture. This result is consistent with Glaster's theory about the importance of housing architecture quality in improving residential satisfaction. Future researches based on the conceptual model of this research help refine it and in this regard, it is suggested that different case studies be investigated with different qualities of the components of social sustainability. It is also recommended that future studies focus on the impact of personal and cultural factors on research variables.

Abbaszadeh, S., Gohari, F., \& Askari Rabori, A. (2017). Analysis of Environmental Quality towards Satisfaction of Users in Mashhad Housing Complexes. Geographical Urban Planning Research, 4(4), 653-671.

Altman, I. (1975). The environment and social behavior: Privacy, personal space, territory, crowding. Monterey (Cal): Brooks/Cole.

Amerigo, M., \& Aragones, J. I. (1997). A THEORETICAL AND METHODOLOGICAL APPROACH TO THE STUDY OF RESIDENTIAL SATISFACTION. Journal of Environmental Psychology, 17, 47-57. https://doi. org/10.1006/jevp.1996.0038

Azemati, H., Pourbagher, S., \& Rostami, V. (2017). Evaluating the Satisfaction Rate in Affordable Housing Case Study: Ardabil Mehr Housing in Ardabil Province of Iran. Journal of Architectural Engineering Technology, 6(2). https://doi.org/10.4172/21689717.1000199

Azimi, N., \& Esmaeilzadeh, Y. (2017). Assessing the relationship between house types and residential satisfaction in Tabriz, Iran. International Journal of Urban Sciences. https://doi.org/10.1080/12265934 .2016.1273128

Azizibabani, M. H., \& Bemanian, M. R. (2019). The Effects of Incremental Housing Approach on The Level of Residential Satisfaction. International Journal of Architecture \& Planning, 7(1), 205-225. https://doi.org/10.15320/ICONARP.2019.73

Bemanian, M., \& Zandi, M. (2018). Iranian housing and lifestyle. Tehran: Aval va Akhar.
Campbell, A., Converse, P. E., \& Rodgers, W. L. (1976). The quality of American life Perceptions, evaluations, and satisfactions.. New York: Russell Sage Foundation.

Choudhury, I. (2005). A conceptual Model of Residential Satisfaction with Reference to Neighborhood Composition. Wirld Congress on Housing. Pretoria.

Colantonio, A., \& Lane, G. (2007). Measuring social sustainability: best practice from urban renewal in the EU. London: Oxford Publication.

Cutter, S. (1982). Residential satisfaction and the suburban homeowner. Urban Geography, 3, 315327. https://doi.org/10.2747/0272-3638.3.4.315

Dekker , K., de Vos, S., Musterd, S., \& van Kempen, R. (2011). Residential satisfaction in housing estates in European cities: A multi-level research approach. Housing Studies, 26(4), 479-499. https://doi.org/10 $.1080 / 02673037.2011 .559751$

Dieleman, F. M. (2001). Modelling residential mobility; a review of recent trends in research. Journal of Housing and the Built Environment, 16, 249-265. https://doi.org/10.1023/A:1012515709292

Fallahi, B., Hariza, A., Husniyah, H., \& Abdul Rahim, B. (2015). Relationship between Background Characteristics and Housing Satisfaction of Iranian Homeowners in Kuala Lumpur, Malaysia. Journal of Educational, Health and Community Psychology, 4(2).

Galster, G. C., \& Hesser, G. W. (1981). Residential satisfaction. Compositional and contextual correlates. Environment and Behavior, 13, 735-758. https://doi.org/10.1177/0013916581136006

\section{References}


Garcia. (1994). Urban environment evaluation : A study of environmental satisfaction and preference. PhD Disertation Universidad de-Santiago de Compostela Spain.

Glaster, G. C. (1985). Evaluating indicators for housing policy: Residential satisfaction vs marginal improvement priorities. Social Indicators Research, 16(4), 415-448. https://doi.org/10.1007/ BF00333289

Howley, P. Scott, M \& Redmond, D. (2009). Sustainability versus liveability: an investigation of neighbourhood satisfaction, Journal of Environmental Planning and Management, 52:6. https://doi. org/10.1080/09640560903083798

Karuppannan, S. and Sivam, A., (2011). Social sustainability and neighbourhood design: an investigation of residents' satisfaction in Delhi. Local Environment, 16 (9), 849-870. https://doi.org/10.1080/1354 9839.2011 .607159

Ibrahim, I.A. (2020). Sustainable housing development: role and significance of satisfaction aspect. City Territ Archit 7, 21. https://doi.org/10.1186/ s40410-020-00130-x

Kim, J. J. (1998). Introduction to Sustainable Design. Michigan: National Pollution Prevention Center for Higher Education.

Lu, M. (1999). Determinants of residential Satisfaction. Growth \& Change, 30(2), 264-288. https://doi. org/10.1111/0017-4815.00113

Marans, R. W., \& Rodgers, S. W. (1975). Toward an understanding of community satisfaction. (A. Hawley, \& V. Rock, Eds.) New York: Halstead Press.

Maslow, A. H. (1958). A Dynamic Theory of Human Motivation. Cleveland USA: Howard Allen Publishers.

McCrea, R. (2007). Urban quality of life: Linking objective dimensions and subjective evaluations of the urban environment. Unpublished PhD thesis, The University of Queensland, Brisbane.

McKenzie, S. (2004). SOCIAL SUSTAINABILITY: TOWARDS SOME DEFINITIONS. Hawke Research Institute.

Morris, E. W., \& Winter, M. (1975). A theory of family housing adjustment. Journal of Marriage and the Family, 37(1), 79-88. https://doi.org/10.2307/351032

Murphy, K. (2012). The Social Pillar of Sustainable Development: A Literature Review and Framework for Policy Analysis. Sustainability: Science, Practice and Policy, 8(1), 15-29. https://doi.org/10.1080/154 87733.2012.11908081

Naghizadeh, M. (2012). Reflection on Understanding the Basics of Iranian Islamic Housing. Art Ketabmah, 170, 38-54.
Nazarpour, M. (2000). Values and development. Case Study: The Constitution of the Islamic Republic of Iran. Tehran: Research Institute of Culture and Thought.

Ogu, V. I. (2002). Urban Residential Satisfaction and the Planning Implications in a Developing World Context : The Example of Benin City, Nigeria. International Planning Studies, 7(1), 37-53. https://doi. org/10.1080/13563470220112599

Parkes, A., Kearns, A., \& Atkinson, R. (2002). What makes people dissatisfied with their neighbourhoods? Urban Studies, 39(13), 2413-2438. https:// doi.org/10.1080/0042098022000027031

Pirnia, M. (1997). Stylistics of Iranian Architecture. (G. Memarian, Ed.) Tehran: Sorush Danesh.

Premius, H. (1986). Housing as a social adaptation process. A conceptual scheme. Environment and behavior, 18, 31-52. https://doi.org/10.1177/0013916586181002

Qanbari, Y., \& Farhadi, S. (2017). Social Sustainability in resedential complex. Tehran: Simaye Danesh.

Raeisi, M. (2019). Architecture and urbanism in accordance with Islamic lifestyle. Qom: Qom university.

Rafieian, M., Aminsalehi, F., \& Taghvaei, A. (2011). Assessing the quality of living environment in Ekbatan town of Tehran. The Journal of Spatial Planning, 14(4), 63-85.

Reimer, S. (1943). Sociological theory of home adjustment. American Sociological Review, 8(3), 272 278. https://doi.org/10.2307/2085080

Ríos, M. L., \&Moreno-Jiménez, M.P. (2012). Placeidentity and residential satisfaction: Differences between native and immigrant populations. Psyecology, 3, 75 86. https://doi.org/10.1174/217119712799240224

Rossi, P. H. (1955). Why families move: A study in the social psychology of urban residential Mobility. Free press.

Russell, N., \& James, I. (2008). Investing in Housing Characteristics that Count: A Cross-Sectional and Longitudinal Analysis of Bathrooms, Bathroom Additions, and Residential Satisfaction. Housing and Society, 35(2), 67-82. https://doi.org/10.1080/0888 2746.2008.11430564

Separe, A. (1974). Residential satisfaction as an intervening variable in residential mobility. Demography, 11, 173-188. https://doi.org/10.2307/2060556

Theodori, G. L. (2001). Examining the effecty of community satisfaction and attachment on individual well being. Rural Sociology, 66(4), 618-628. https:// doi.org/10.1111/j.1549-0831.2001.tb00087.x

Thin, N., Lockhart, C., \& Yaron, G. (2002). Conceptualising Socially Sustainable Development. New York: Mimeo. 
Varady, D. P., Preiser, \& Wolfgang. (1998). Scattered site public housing and housing satisfaction. Journal of the American Planning Association, 64(2), 189208. https://doi.org/10.1080/01944369808975975

WCED. (1987). Report of the World Commission on Environment and Development: Our Common Future. United Nations General Assembly.

Weingaertner, C., \& Moberg, Å. (2011). Exploring Social Sustainability: Learning from Perspectives on Urban Development and Companies and Prod- ucts. Sustainable Development, 22(2), 122-133. https://doi.org/10.1002/sd.536

Wolpert, J. (1966). Migration as an adjustment to environmental stress. Journal of Social Issues, 22(4), 92-102. https://doi.org/10.1111/j.1540-4560.1966. tb00552.x

Zabihi, H., Habib, F., \& Rahbarimanesh, K. (2011). Relevance Between Acquiescence of Habitations and Impacts on Relationships (Case Study: Ekbatan and Behjatabad Tehran). Hoviatshahr, 5(8), 103-118.

\section{MOHAMMADHOSSEIN AZIZIBABANI}

Ph.D.

Student in Architecture, Department of Architecture, Faculty of Art, Tarbiat Modares University, Tehran, Iran

\section{Main research area}

Affordable Housing Design, Sustainable Design

\section{Address}

Faculty of Art, Tarbiat Modares University, Tehran, Iran.

Tel. +989120929844

E-mail: M.azizibabani@modares.ac.ir

\section{MOHAMMADREZA BEMANIAN}

Professor

Department of Architecture, Faculty of Art, Tarbiat Modares University, Tehran, Iran

\section{Main research area}

Iranian Islamic architecture, Architectural planning and management

\section{Address}

Faculty of Art, Tarbiat Modares University, Tehran, Iran.

Tel. +98(21)82883711

E-mail: Bemanian@modares.ac.ir

\section{MANSOUR YEGANEH}

Assistant Professor

Department of Architecture, Faculty of Art, Tarbiat Modares University, Tehran, Iran

\section{Main research area}

Architecture and Converging Technologies, Behavioral and Cognitional Territories in Architecture, New Methods in Architectural Design, Modeling and Fabrication. Architecture and Renewable and New Energies

\section{Address}

Tel. +98(21)8288371108

E-mail: Yeganeh@modares.ac.ir

\section{About the Authors}

